Article

\title{
Relationship of the compositional content and sanitary quality of Holstein cows' milk of the high tropic of Nariño
}

Henry Armando Jurado-Gámez ${ }^{a^{*}}$

Carlo Eugenio Solarte-Portilla ${ }^{\text {a }}$

Álvaro Javier Burgos-Arcos b

Aldemar González-Rodríguez ${ }^{\text {b }}$

Carol Rosero-Galindo ${ }^{b}$

${ }^{\text {a }}$ Universidad de Nariño. Departamento de Producción y Procesamiento Animal, Programa de Zootecnia., Cll 18 N 50-02 Torobajo, Municipio de Pasto, Nariño, Colombia.

${ }^{\mathrm{b}}$ Universidad de Nariño. Colombia.

* Corresponding author: henryjugam@gmail.com

\begin{abstract}
:
Agricultural production seeks to obtain high quality, safe products for human consumption- a great concern for the dairy chain. The present investigation seeks to identify the correlation between the compositional and sanitary quality of raw milk (SCC/mL). The investigation was carried out in three districts of the Department of Nariño, Colombia. For this purpose, sampling and information collection was executed throughout the years 2016 and 2017. To determine the relationship between composition and sanitary quality, an analysis was made of the principal components of the milk, and a design of mixed models was creating using selected variables. The analysis showed that there is a relationship between the compositional variables, and the mixed model indicated that there is a significant relationship between the somatic cell count and the milk quality of the region. It was concluded that a somatic cell count above 500,000 $\mathrm{CFU} / \mathrm{mL}$ has negative effects on protein, casein, and milk production.
\end{abstract}

Key words: Food safety, Animal health, Public health. 
Received: $17 / 11 / 2018$

Accepted: 29/04/2019

\section{Introduction}

Agricultural production worldwide requires high quality, safe products for human consumption, a constant search which concerns all the constituents of the dairy chain. This process begins on the farm and must be enforced in order to guarantee the best conditions for obtaining a product of optimum quality ${ }^{(1)}$.

In Colombia, specialized dairy industries are located in high tropical areas such as the Altiplano Cundíboyacense, the Nariño Altiplano and the north and northeast highlands of Antioquia. These systems are characterized by the presence of Bos taurus, intensive use of production factors (land, capital and labor), use of fertilizers, irrigation, rotation of pastures, use of food supplements and two daily milking. The improvement of the hygienic quality of milk is carried out through a simple process, showing rapid results that begin with the improvement of milking practices in order to avoid milk contamination, while maintaining perfect hygienization of the milk canteens or storage tanks ${ }^{(2)}$.

This type of livestock activity must adhere to Decree 616 of 2006 of Colombian regulations, which outlines the requirements that must be met by bovine, buffalo, and goat milk destined for human consumption, in order to protect life, health, and security and prevent practices that may mislead, confuse, or deceive consumers ${ }^{(2)}$.

In this regard, Benbrook et $a l^{(3)}$ defines high-quality milk as having an excellent composition (fat, protein, lactose, vitamins and minerals), low microbial counts (hygienic), is free of pathogens, and has no physical-chemical contaminants. Quality milk is an indispensable requirement for good quality products, and the herd is the first condition in achieving good products.

According to Ministry of Agriculture Resolution 000017 of $2012^{(4)}$, the hygienic quality of milk refers to the hygiene level of the process through which milk is obtained and handled. In this order of ideas, the somatic cell count per milliliter $(\mathrm{SCC} / \mathrm{mL})$ in most cases can be associated with diseases such as mastitis, an inflammatory reaction of the mammary gland, which produces physical and chemical alterations in milk, an increase in the number of somatic cells due to the presence of pathogenic microorganisms, and changes such as the loss of functionality ${ }^{(1)}$. 
For this reason, the somatic cell count (SCC) is one of the most influential parameters in determining the udder health and milk quality. SCC in milk increases in direct proportion to the severity of the infectious disease. In a milk that does not contain subclinical mastitis, the SCC is low $(<100,000 \mathrm{SCC} / \mathrm{mL})$. The increase in SCC depends on the pathogen that causes mastitis ${ }^{(5)}$. High SCC is associated with inflammation of the udder, which leads to bacteriological problems in milk, an alteration in its composition, and changes in the characteristics of dairy products when compared to normal values ${ }^{(6)}$. However, in addition to its immune function in the udder and protective functions in milk, it has recently been shown that SCC have a positive influence on the composition and technological properties of dairy products, which influence the final quality of the dairy products through its endogenous enzymes $^{(7)}$.

In Nariño, as is the case with the rest of Latin America, there is little information on the compositional and sanitary quality of the production and commercialization of raw milk. Along with the above, the lack of responsibility of the producers of milk for the quality of their product (in spite of the Colombian law that establishes health and safety regulations) increases the uncertainty about the quality variables of the products produced in the region. Based on the above, the objective of the present investigation was to evaluate the compositional and hygienic quality of the raw milk received from the different districts evaluated in the Department of Nariño, as well as to observe the relation of the sanitary quality on its compositional profile.

\section{Material and methods}

\section{Location}

Information from 87 farms specialized in milk production was evaluated. The farms are distributed among three districts belonging to the Department of Nariño; 39 from the district of Guachucal, 24 farms from Pasto, and 24 from Pupiales. These geographical areas are located between 2,527 and 3,180 m asl, with an average annual temperature between 8 and $12{ }^{\circ} \mathrm{C}^{(8)}$.

\section{Selection of samples}

The selected farms managed a standardized record system for milking (twice a day) information and a routine management program of the CMT test. A total of 11,293 samples from 1,659 lactations of Holsteins from the districts of Guachucal, Pasto, and Pupiales were evaluated. Various variables were determined, including: precipitation $(\mathrm{mm} / \mathrm{month})$, milk production $(\mathrm{kg})$, 
density $(\mathrm{g} / \mathrm{mL})$, day of lactation, calving interval, age of the cow (years), delivery number, kilograms of fat, protein, casein, of total solids, and somatic cell count ( $\mathrm{SCC} / \mathrm{mL})$.

The samples were taken at the time of milking, and the identification, conservation, and transport of the samples was carried out according to the protocol established by CORPOLAC. Sampling was done every $3 \mathrm{wk}$ on each farm. The samples were analyzed at a compositional and sanitary level in the laboratories of the MEGA (Mejoramiento Genético Animal) research group located in the University of Nariño, Torobajo. The milk samples were analyzed in a MilkoScan ${ }^{\mathrm{TM}}$ FT1, determining the compositional profile of the milk according to the protocol established by the manufacturer of the equipment. A $100 \mathrm{~mL}$ sample of raw cow's milk was used for this process (SGC-PR-04 daily procedure for the management of the MilkoScan FT1 equipment). The analysis of the sanitary profile was created using EkoMilk Scan ${ }^{\circledR}$ equipment, according to the protocol established by the manufacturer (SGC-PR-05 daily procedure for the operation of EKOMILSCAN equipment- SGC-FT-02 EKOMILKSCAN technical data). The somatic cell count was performed using a PortaSCC® test.

\section{Statistical analysis}

The data was evaluated through descriptive statistics. The relationship between variables was determined by Pearson's correlation after the standardization of the variables to ensure a better fit of the results. The values of fat, protein, total solids, and casein were transformed into kilograms using the formula proposed in resolution 000017 of 2012 by the Ministry of Agriculture and Rural Development (MADR) ${ }^{(4)}$ :

\section{Value $\mathrm{kg}$ value $\% *$ milk density $* 10$}

For production, which is expressed in liters, the density was used to convert the value to kilos Kg milk density $*$ volume (l)

The somatic cell count variable was transformed to somatic cell score by the formula proposed by Ali and Shook ${ }^{(9)}$ in order to correct the normality of the variable somatic cell score (SCR):

SCR $((\log 2(\operatorname{SCC} / 100.000))+3$

The relationship between the variables was determined through a principal component analysis (PCA) with rotation (varimax method) in order to identify the related groups.

With the variables selected through the PCA, a mixed model was created, where the farm and the animal nested within the farm were used as random factors and the precipitation with the dry and rainy season levels and the somatic cell count as fixed factors. The SCC was categorized into four levels, as follows: <2’000,000, 201,000 to 5000,00, 501,000 to 999,000 and $>1^{\prime} 000,000$. Protein, fat, casein, total solids and production was considered dependent variable $^{(10)}$. Statistical analyzes were performed with the statistical package SPSS ${ }^{(11)}$. 


\section{Results}

The mean and standard error of the mean of the variables can be seen in Table 1 and the correlation in Tables 2, 3 and 4. The means for the three districts show that the density was the same. Precipitation, total solids, day of lactation, calving interval, age, and number of deliveries showed similar results. On the contrary, the data collected for production, fat, protein and casein varied, with Pupiales showing the highest values, followed by Pasto and finally Guachucal.

Table 1: Descriptive statistics of production and compositional parameters

\begin{tabular}{lllllll}
\hline & \multicolumn{2}{l}{ Guachucal } & Pasto & \multicolumn{3}{c}{ Pupiales } \\
& Mean & SEM & Mean & SEM & Mean & SEM \\
\hline Precipitation, mm/mo & 101.691 & 0.5511 & 99.749 & 0.9630 & 101.980 & 1.4078 \\
Production, kg & 16.592 & 0.0730 & 19.621 & 0.1366 & 20.673 & 0.1951 \\
Density, g/mL & 1.031 & 0.0001 & 1.031 & 0.0002 & 1.031 & 0.0001 \\
Day lactation, day & 182.427 & 1.2939 & 173.892 & 1.9738 & 163.128 & 2.9465 \\
Calving interval, day & 452.668 & 1.3196 & 431.900 & 1.9461 & 431.901 & 3.0784 \\
Year & 5.754 & 0.0258 & 5.635 & 0.0467 & 5.593 & 0.0653 \\
Delivery number & 2.918 & 0.0195 & 3.034 & 0.0376 & 3.020 & 0.0482 \\
Fat, kg & 0.653 & 0.0030 & 0.755 & 0.0054 & 0.775 & 0.0075 \\
Protein, kg & 0.560 & 0.0023 & 0.640 & 0.0042 & 0.693 & 0.0064 \\
Total solid, kg & 2.133 & 0.0092 & 2.130 & 0.0220 & 2.585 & 0.0253 \\
Casein, kg & 0.426 & 0.0018 & 0.831 & 0.0153 & 0.557 & 0.0056 \\
SCC, SCC/mL & 3.313 & 0.0104 & 3.209 & 0.0141 & 3.350 & 0.0261 \\
\hline
\end{tabular}

$\mathrm{SEM}=$ standard error of the mean.

The correlation shows that the compositional variables and production are highly related and this set of variables are negatively related to the days of lactation. There is also a highly significant relationship $(P<0.01)$ between day of lactation and calving interval, and also between the number of births and age. Finally, the somatic cell count shows a significant relationship $(P<0.05)$ with production, protein, and casein. The other variables show low correlation. 
Table 2: Matrix of correlation Guachucal

\begin{tabular}{|c|c|c|c|c|c|c|c|c|c|c|c|c|}
\hline & Pr1 & Pr2 & D & DI & $\mathbf{C i}$ & $\mathbf{Y}$ & Dn & $\mathbf{F}$ & Pr3 & Ts & $\mathbf{C}$ & SCC \\
\hline Pr1 & 1 & & & & & & & & & & & \\
\hline Pr2 & -0.02 & 1 & & & & & & & & & & \\
\hline D & 0.017 & -0.009 & 1 & & & & & & & & & \\
\hline Dl & 0.004 & $-.458^{*}$ & 0.031 & 1 & & & & & & & & \\
\hline $\mathrm{Ci}$ & 0.02 & $-.291^{*}$ & 0.129 & $.694^{\text {** }}$ & 1 & & & & & & & \\
\hline $\mathbf{Y}$ & 0.01 & 0.068 & $\begin{array}{l}- \\
0.171^{*}\end{array}$ & 0.129 & $0.156^{*}$ & 1 & & & & & & \\
\hline Dn & 0.01 & 0.111 & -0.116 & 0.015 & 0.059 & $.922^{* *}$ & 1 & & & & & \\
\hline $\mathbf{F}$ & -0.02 & $.852^{* *}$ & 0.019 & $\begin{array}{l}- \\
0.357^{*}\end{array}$ & $-.229^{*}$ & 0.055 & 0.132 & 1 & & & & \\
\hline Pr3 & $\begin{array}{l}- \\
0.016\end{array}$ & $.949^{* *}$ & 0.063 & $-.335^{*}$ & $-.231^{*}$ & 0.059 & 0.137 & $.864^{* * *}$ & 1 & & & \\
\hline Ts & $\begin{array}{l}- \\
0.019\end{array}$ & $.974^{* *}$ & 0.036 & $-.418^{*}$ & $-.278^{*}$ & 0.046 & 0.132 & $.934^{* * *}$ & $.967^{* *}$ & 1 & & \\
\hline C & $\begin{array}{l}- \\
0.027\end{array}$ & $.962^{* * *}$ & 0.053 & $-.342^{*}$ & $-.236^{*}$ & 0.063 & 0.142 & $.861^{* *}$ & $.996^{* *}$ & $.971^{* * *}$ & 1 & \\
\hline SCC & $\begin{array}{l}- \\
0.012\end{array}$ & $\begin{array}{l}- \\
0.254^{*}\end{array}$ & -0.048 & 0.135 & 0.123 & 0.145 & 0.128 & $\begin{array}{l}- \\
0.029\end{array}$ & $\begin{array}{l}- \\
0.386^{*}\end{array}$ & $\begin{array}{l}- \\
0.054\end{array}$ & $\begin{array}{l}- \\
0.394^{*}\end{array}$ & 1 \\
\hline
\end{tabular}

$\operatorname{Pr} 1=$ precipitation, $\mathrm{Pr} 2=$ production, $\mathrm{D}=$ density, $\mathrm{DL}=$ day of lactation, $\mathrm{Ci}=$ calving interval, $\mathrm{Y}=$ years, $\mathrm{Dn}=$ delivery number, $\mathrm{F}=$ fat, $\mathrm{Pr} 3=$ protein, $\mathrm{Ts}=$ total solids, $\mathrm{C}=$ casein, $\mathrm{SCC}=$ somatic cell count.

Table 3: Matrix of correlation Pasto

\begin{tabular}{lllllllllllll}
\hline & Pr1 & Pr2 & D & DI & Ci & Y & Dn & F & Pr3 & Ts & C & SCC \\
\hline Pr1 & 1 & & & & & & & & & & & \\
Pr2 & 0.007 & 1 & & & & & & & & & & \\
D & -0.011 & -0.023 & 1 & & & & & & & & & \\
Dl & -0.009 & $-0.455^{*}$ & 0.036 & 1 & & & & & & & & \\
Ci & 0.054 & $-0.240^{*}$ & 0.081 & $0.566^{*}$ & 1 & & & & & & & \\
Y & -0.012 & -0.017 & -0.047 & $0.180^{*}$ & 0.174 & 1 & & & & & & \\
Dn & 0.020 & 0.073 & -0.088 & 0.045 & 0.105 & $0.910^{* *}$ & 1 & & & & & \\
F & 0.007 & $0.830^{* *}$ & -0.061 & $-0.381^{*}$ & -0.224 & -0.040 & 0.019 & 1 & & & & \\
Pr3 & 0.017 & $0.944^{* *}$ & 0.048 & $-0.352^{*}$ & -0.220 & -0.048 & 0.022 & $0.839^{* *}$ & 1 & & & \\
Ts & 0.012 & $0.970^{* *}$ & 0.002 & $-0.439^{*}$ & -0.257 & -0.054 & 0.026 & $0.922^{* *}$ & 0.962 & 1 & & \\
C & 0.011 & $0.907^{* *}$ & 0.042 & $-0.324^{*}$ & -0.205 & -0.029 & 0.032 & $0.785^{* *}$ & 0.942 & 0.891 & 1 & \\
SCC & -0.008 & $-0.234^{*}$ & -0.006 & 0.125 & 0.102 & 0.131 & 0.106 & -0.117 & $-0.206^{*}$ & -0.112 & $-0.213^{*}$ & 1 \\
\hline
\end{tabular}

$\operatorname{Pr} 1=$ Precipitation, $\operatorname{Pr} 2=$ production, $\mathrm{D}=$ density, $\mathrm{Dl}=$ day of lactation, $\mathrm{Ci}=$ calving interval, $\mathrm{Y}=$ years, $\mathrm{Dn}=$ delivery number, $\mathrm{F}=$ fat, $\mathrm{Pr} 3=$ protein, $\mathrm{Ts}=$ total solids, $\mathrm{C}=$ casein, $\mathrm{SCC}=$ somatic cell count. 
Table 4: Matrix of correlation Pupiales

\begin{tabular}{lllllllllllll}
\hline & Pr1 & Pr2 & D & Dl & Ci & Y & Dn & F & Pr3 & Ts & C & SCC \\
\hline Pr1 & 1 & & & & & & & & & & & \\
Pr2 & 0.021 & 1 & & & & & & & & & & \\
D & 0.106 & 0.063 & 1 & & & & & & & & & \\
DI & -0.046 & $-0.389^{*}$ & 0.024 & 1 & & & & & & & & \\
Ci & -0.013 & $-0.253^{*}$ & $0.165^{*}$ & $0.651^{* *}$ & 1 & & & & & & & \\
Y & -0.020 & -0.040 & $-0.180^{*}$ & $0.159^{*}$ & $0.179^{*}$ & 1 & & & & & & \\
Dn & -0.010 & 0.070 & $-0.185^{*}$ & 0.002 & 0.069 & $0.871^{* *}$ & 1 & & & & & \\
F & 0.080 & $0.786^{* *}$ & 0.076 & $-0.312^{*}$ & $-0.264^{*}$ & -0.001 & 0.075 & 1 & & & & \\
Pr3 & 0.022 & $0.949^{* *}$ & 0.126 & $-0.263^{*}$ & $-0.203^{*}$ & -0.064 & 0.047 & $0.790^{* *}$ & 1 & & & \\
Ts & 0.081 & $0.947^{* *}$ & 0.124 & $-0.344^{*}$ & $-0.272^{*}$ & -0.087 & 0.030 & $0.884^{* *}$ & $0.942^{* *}$ & 1 & & \\
C & -0.125 & $0.659^{* *}$ & 0.038 & $-0.230^{*}$ & -0.085 & 0.122 & 0.142 & $0.512^{*}$ & $0.670^{* *}$ & 0.509 & 1 & \\
SCC & -0.001 & $-0.183^{*}$ & -0.055 & 0.069 & 0.070 & $0.232^{*}$ & 0.134 & -0.071 & $-0.189^{*}$ & -0.106 & $-0.207^{*}$ & 1 \\
\hline
\end{tabular}

$\operatorname{Pr} 1=$ Precipitation, $\operatorname{Pr} 2=$ production, $\mathrm{D}=$ density, $\mathrm{Dl}=$ day of lactation, $\mathrm{Ci}=$ calving interval, $\mathrm{Y}=$ years, $\mathrm{Dn}=$ delivery number, $\mathrm{F}=$ fat, $\mathrm{Pr} 3=$ protein, $\mathrm{Ts}=$ total solids, $\mathrm{C}=$ casein, $\mathrm{SCC}=$ somatic cell count.

The results of the analysis of the principal components can be seen in Tables 5 and 6 . For the three districts, four components were analyzed, representing 79.97, 77.04, and $75.53 \%$ of the variability explained, for the Guachucal, Pasto and Pupiales respectively. As in the correlation analysis, the results show that production, fat, protein, casein and total solids are highly related and represent the first axis (compositional). Both age and number of parturition constitute the second axis, while the third axis is formed by the variables day of lactation and calving interval. The relationship found for these last two axes, however, may be a consequence of time.

Table 5: Results of the variance observed in the axes used

\begin{tabular}{lllll}
\hline & Initial & $\begin{array}{l}\text { Extraction } \\
\text { Guachucal }\end{array}$ & Pasto & Pupiales \\
\hline Precipitation & 1.000 & 0.856 & 0.881 & 0.856 \\
Production & 1.000 & 0.953 & 0.946 & 0.935 \\
Density & 1.000 & 0.361 & 0.313 & 0.473 \\
Day lactation & 1.000 & 0.772 & 0.704 & 0.741 \\
Calving interval & 1.000 & 0.810 & 0.738 & 0.820 \\
Year & 1.000 & 0.928 & 0.935 & 0.901 \\
Delivery number & 1.000 & 0.910 & 0.937 & 0.868 \\
Fat & 1.000 & 0.853 & 0.823 & 0.785 \\
Protein & 1.000 & 0.965 & 0.959 & 0.939 \\
Total solid & 1.000 & 0.991 & 0.980 & 0.930 \\
Casein & 1.000 & 0.969 & 0.894 & 0.624 \\
SCC & 1.000 & 0.223 & 0.133 & 0.172 \\
\hline
\end{tabular}


Table 6: Variability of the components

\begin{tabular}{|c|c|c|c|c|c|c|c|c|c|c|c|c|}
\hline \multicolumn{13}{|c|}{ Rotated Component Matrices } \\
\hline & \multicolumn{4}{|c|}{ Guachucal } & \multicolumn{4}{|c|}{ Pasto } & \multicolumn{4}{|c|}{ Pupiales } \\
\hline & $\mathbf{1}$ & 2 & 3 & 4 & 1 & 2 & 3 & 4 & 1 & 2 & 3 & 4 \\
\hline Precipitation & -.032 & .086 & .062 & .918 & .029 & -.043 & .052 & .936 & -.026 & 0.086 & -.091 & .916 \\
\hline Production & .956 & .054 & -.188 & .008 & .956 & .026 & -.180 & .003 & 0.951 & -.036 & -.168 & .019 \\
\hline Density & .138 & -.368 & .398 & .219 & .096 & -.214 & .399 & -.316 & 0.172 & -.311 & .397 & .435 \\
\hline Day lactation & -.323 & .090 & .806 & -.095 & -.327 & .087 & .767 & .041 & -.263 & 0.091 & .812 & -.070 \\
\hline Calving interval & -.168 & .084 & .879 & -.043 & -.126 & .098 & .833 & .139 & -.136 & 0.123 & .887 & .007 \\
\hline Year & .050 & .954 & .122 & -.010 & -.007 & .958 & .133 & -.006 & 0.026 & 0.939 & .116 & -.063 \\
\hline Delivery number & .128 & .945 & .025 & .009 & .056 & .966 & .019 & .032 & 0.114 & 0.924 & -.021 & -.042 \\
\hline Fat & .917 & .034 & -.102 & -.004 & .893 & -.007 & -.162 & .023 & 0.862 & -.002 & -.167 & .121 \\
\hline Protein & .980 & .026 & -.064 & .006 & .975 & -.028 & -.080 & -.008 & 0.964 & -.064 & -.056 & .032 \\
\hline Total solid & .985 & .021 & -.141 & .013 & .975 & -.020 & -.169 & .002 & 0.938 & -.087 & -.158 & .132 \\
\hline Casein & .981 & .031 & -.075 & -.002 & .943 & -.014 & -.064 & -.011 & 0.745 & 0.106 & .012 & -.238 \\
\hline SCC & -.184 & .089 & .036 & -.345 & -.152 & .196 & .062 & -.226 & -.071 & 0.012 & 0.046 & .248 \\
\hline
\end{tabular}

The fourth axis is represented by precipitation. It should be noted that the somatic cell count is not well represented in some of the four components evaluated, however, it is observed that there is a contribution to the components one and four in the three districts, indicating some degree of relationship between these components.

The results of the mixed model analysis can be seen in Table 7. The variables fat and total solids were not affected by season and SCC $(P>0.05)$. In the case of production, protein and casein, the results showed that cell count do have significant influence $(P<0.05)$.

Table 7: Mixed model coefficients

\begin{tabular}{|c|c|c|c|c|c|c|c|c|}
\hline \multirow{2}{*}{ Parameter } & \multirow{2}{*}{ Ss } & \multicolumn{4}{|c|}{ SCC (range) } & \multicolumn{3}{|c|}{$P$-value } \\
\hline & & $\leq 200$ & 201-500 & 501-999 & $\geq 1000$ & Ss & SCC & $\mathrm{Ss} * \mathrm{SCC}$ \\
\hline \multirow{2}{*}{ Production } & 0 & 18.02 & 16.92 & 15.93 & 14.84 & \multirow{2}{*}{0.755} & \multirow{2}{*}{0.048} & \multirow{2}{*}{0.444} \\
\hline & 1 & 17.97 & 17.05 & 15.76 & 14.21 & & & \\
\hline \multirow{2}{*}{ Fat } & 0 & 0.684 & 0.672 & 0.673 & 0.672 & \multirow{2}{*}{0.315} & \multirow{2}{*}{0.123} & \multirow{2}{*}{0.355} \\
\hline & 1 & 0.692 & 0.683 & 0.685 & 0.681 & & & \\
\hline \multirow{2}{*}{ Protein } & 0 & 0.597 & 0.577 & 0.559 & 0.541 & \multirow{2}{*}{0.757} & \multirow{2}{*}{0.011} & \multirow{2}{*}{0.827} \\
\hline & 1 & 0.591 & 0.573 & 0.555 & 0.545 & & & \\
\hline \multirow{2}{*}{ Total solids } & 0 & 2.216 & 2.122 & 2.197 & 2.181 & \multirow{2}{*}{0.248} & \multirow{2}{*}{0.148} & \multirow{2}{*}{0.328} \\
\hline & 1 & 2.168 & 2.131 & 2.148 & 2.105 & & & \\
\hline \multirow{2}{*}{ Casein } & 0 & 0.530 & 0.483 & 0.446 & 0.424 & \multirow{2}{*}{0.103} & \multirow{2}{*}{0.022} & \multirow{2}{*}{0.201} \\
\hline & 1 & 0.543 & 0.494 & 0.450 & 0.429 & & & \\
\hline
\end{tabular}




\section{Discussion}

The interpretation of the results was made considering current Colombian regulations, which revolves around Decree $616^{(12)}$ and Resolution $000017^{(4)}$, responsible for guaranteeing the safety of human milk consumption and the compositional and sanitary quality of milk. Based on the information provided by the statistical analysis, it can be established that the compositional quality is closely related to milk production. It was also observed that the SCC does not affect the compositional quality of the same, and that there is no evidence to support this premise.

In this regard, various authors found values of $24.28 \mathrm{~kg}$ of milk, which is higher than that found in the three districts ${ }^{(13)}$. Manterola ${ }^{(14)}$ reported an average production of $20 \mathrm{~kg} / \mathrm{d} / \mathrm{cow}$ of milk, and points out that age is a minor factor if the replacement rate is normal, though it does have a greater effect on the volume of production and thereby on the content of total solids. This was proven through the high correlation between production and the compositional parameters of the milk. Various authors also mention that the milk production of a cow is the result of the relationship of the environment and the inheritance ${ }^{(15)}$. Precipitation, however, did not show significant relationships with these variables, as is observed in the diagram of the two components of PCA, the precipitation is very close to the cutoff point of the two coordinate axes.

The Ministry of Social Protection, through decree 616, has established that the density of raw milk at $15{ }^{\circ} \mathrm{C}$ ranges between 1.030 and $1.033 \mathrm{~g} / \mathrm{cm}^{3}$. In this sense, the milk density of the samples evaluated fall within the regulatory framework. Other authors found an average value of $1.032 \mathrm{~g} / \mathrm{cm}^{3}$ in the milk samples evaluated, and concluded that milk from healthy animals compared to that of animals with subclinical mastitis do not show variation in the density value $^{(2)}$. In animals with mastitis, however, the reflected density is affected by values lower than $1.029 \mathrm{~g} / \mathrm{ml}$.

A study indicates that the composition of milk determines nutritional and industrial quality, which directly affects the profitability and competitiveness of milk production systems ${ }^{(16)}$. Composition depends on the availability of blood precursors that reach the mammary gland, which can be manipulated through nutrition to vary milk components, though this factor was not evaluated in the present investigation.

It was found that the raw milk received from the three districts complies with the parameters established by Decree 616 of 2006 regarding fat. The average value of the districts surpasses that reported by other authors with an average of $0.577 \mathrm{~kg}$ fat, implying an optimal value of milk fat for Holstein dairy ${ }^{(17)}$. On the other hand, Gallego-Castro et $a^{(13)}$ reported values of 0.84 $\mathrm{kg}$ of milk protein for Holstein and Manterola ${ }^{(14)}$ reported $0.90 \mathrm{~kg}$ of milk per cow per day. A study's suggest that variations in the production of milk fat within a group of cows fed in similar 
conditions, depends on the individual metabolic capacity of each animal ${ }^{(18)}$. It should, however, be taken into account that the values observed in the districts of Pasto and Pupiales demonstrate higher levels of fat per day cow compared to the district of Guachucal. These differences may be the result of the handling of the herds in the area, though the present study cannot corroborate this hypothesis, as management variables could not be included in the analysis. On the other hand, biochemical adaptations of lipid metabolism depended directly on the stage of lactation of the cows. High values in milk fat during early lactation (5.49\%) suggest a lipid mobilization from body fat deposits, a factor that is not observed in the present investigation.

Protein values comply with the parameters established by Decree 616 of 2006. Other authors report lower protein content per day cow, with an average value of $0.451 \mathrm{~kg}$ of $\operatorname{protein}^{(17)}$. In this regard, other articles found values of 0.67 and $0.7 \mathrm{~kg}$ of protein ${ }^{(13,14)}$, values close to those found in the present investigation. Various authors state that the protein concentration of milk does not present outstanding changes with nutritional manipulation ${ }^{(19)}$. However, the effect of soybean meal on nitrogen use and protein production in Holstein cows has been evaluated, reaching conclusions that milk and protein yield do not show an increase with a supplementation level of soybean meal higher than $16.5 \%$.

As an alternative to nutritional manipulation, the effect of genetic variants and haplotypes on the protein composition of milk has been studied. In a study conducted with 1,912 Holstein cows, the authors indicated that the genotypes $\beta-\mathrm{CN}$ and $\kappa-\mathrm{CN}$ haplotype $\mathrm{A}^{2} \mathrm{~B}$, were associated with protein yield and protein/ $\mathrm{L}$ of milk concentration respectively ${ }^{(20)}$. The authors mentioned that selection of these genotypes and haplotypes would result in cows that produce milk better suited for cheese production. In a separate investigation, the author suggested that knowledge of genetic variability could be useful when altering the composition of milk protein, since the estimation of the genetic parameters of the six main milk proteins determined by capillary electrophoresis in zone are highly related ${ }^{(21)}$. According to García et $a l^{(19)}$, this information suggests the possibility of modifying the protein composition of cow's milk through selective breeding, which in turn offers the opportunity to satisfy the new consumer demands.

Casein results reported an average value of $0.454 \mathrm{~kg}$, which in contrast to that found by other authors with values of $2.4 \%$, presents a desirable and superior casein value of within milk production $^{(22)}$. Recent research claims that casein constitutes about $78 \%$ of milk proteins, and precipitate when the milk is acidified to a $\mathrm{pH}$ of $4.6^{(19)}$. They also state that casein is mainly linked to calcium phosphate $\mathrm{Ca}_{3}\left(\mathrm{PO}_{4}\right)_{2}$ in a solid and spongy structure called casein micelle, an important component for cheese making. The treatment of milk with the chymosin enzyme of the rennet of suckling calves produces the destabilization of micelle, as the $\kappa$-casein $(\kappa-\mathrm{CN})$ loses its hydrophilic region by proteolysis in the caseinomacropeptide segment, facilitating the addition of the para- $\kappa-\mathrm{CN}$ fragment ${ }^{(23)}$. As this protein component is fundamentally hydrophobic, the casein content directly influences the coagulation time of all cheeses, and therefore quality and yield ${ }^{(24)}$. 
For total solids, it was found that the raw milk received from the three districts meets the parameters established by Decree 616 of 2006, indicating excellent milk quality ${ }^{(4,12)}$. Similarly, other authors reported values of $1.351 \mathrm{~kg}$ of total solids, a value that is lower than that found in this study ${ }^{(25)}$.

A national somatic cell standard was not adopted, as it does not exist in Colombian legislation. For Decree 616 of 2006 and Resolution 00017 of 2012 of the MADR, the SCC benefits are voluntary and discretionary for the companies that wish to improve this aspect of the quality of the milk. Even so, companies like Colanta report that values below 400,000 SCC/ $\mathrm{mL}$ and up to $200,000 \mathrm{SCC} / \mathrm{mL}$ are rewarded with $\$$ USD 0.007 per liter. Additionally, if the values are below $200,000 \mathrm{SCC} / \mathrm{mL}$ the incentive increases to $\$ 0.01$. If they are above $1,000,000 \mathrm{SCC} / \mathrm{mL}$, the milk is not received, and a deduction is made ${ }^{(24)}$.

Currently, one quarter of the mammary gland is considered healthy; that which does not show any external pathological changes, when the milk is free of pathogenic microorganisms, and has a somatic cell level of $<100,000 \mathrm{CFU} / \mathrm{mL}^{(26)}$. The results of the mixed model indicate that counts higher than $500,000 \mathrm{CFU} / \mathrm{mL}$ affect the compositional quality of milk, decreasing production as well as protein and casein contents the milk. In this regard, other studies found similar results in Canadian Holstein cows, demonstrating that subclinical mastitis affects the compositional quality of milk ${ }^{(27)}$.

\section{Conclusions and implications}

Somatic cell count affects protein, casein, and production variables in the specialized milk systems of Guachucal, Pasto and Pupiales.

\section{Literature cited:}

1. Calderón A, Rodríguez V, Virginia, C. Prevalencia de mastitis bovina y su etiología infecciosa en sistemas especializados en producción de leche en el altiplano cundiboyacense (Colombia). Rev Colombiana Cienc Pecu 2008;21(4):582-589.

2. Calderón A, Arteaga MR, Rodríguez VC, Arrieta GJ, Bermudez DC, Villareal VP. Efecto de la mastitis subclínica sobre el rendimiento en la fabricación del queso costeño. Biosalud 2011;10(2):16-27. 
3. Benbrook CM, Butler G, Latif MA, Leifert C, Davis DR. Organic production enhances milk nutritional quality by shifting fatty acid composition: A United States-wide, 18-month study. Plos One 2013;8(12):82429.

4. Colombia. Ministerio de Agricultura y Desarrollo Rural. Resolución 000017. 2012. Por la cual se establece el sistema de pago de la Leche Cruda al Proveedor. (20 enero de 2012). Bogotá. 2012.

5. Rodríguez V, Acosta A, Calderón-Rangel A. Calidad de leches crudas en sistemas doble propósito en Córdoba (Colombia), en condiciones de máxima y mínima precipitación. Rev Cienc Agr 2015;12(2):51-58.

6. Le Maréchal C, Thiéry R, Vautor E, Le-Loir Y. Mastitis impact on technological properties of milk and quality of milk products—a review. Dairy Sci Technol 2011;91:247-282.

7. Sanchez-Macias D, Morales-de la Nuez A, Torres A, Hernández-Castellano L, JiménezFlores R, Castro N, Arguello A. Effects of addition of somatic cells to caprine milk on cheese quality. International Dairy J 2013;29(2):61-67.

8. Navia J, Muñoz D, Solarte J. Caracterización biofísica y socioeconómica de fincas ganaderas de leche en el municipio de Guachucal, Nariño. Rev Temas Agrarios 2015; 20(1):113-129.

9. Ali A, Shook G. An optimum transformation for somatic cell concentration in milk. J Dairy Sci 1984;63:487-490.

10. Cinar M, Serbester U, Ceyhan A, Gorgulu M. Effect of somatic cell count on milk yield and composition of first and second lactation dairy cows. Italian $\mathbf{J}$ Anim Sci 2015;14(1):3640- 3646 .

11. IBM Corp. Released 2010. IBM SPSS Statistics for Windows, Version 19.0. Armonk, NY: IBM Corp. 2010.

12. Colombia. Ministerio de la Protección Social. Decreto 616. Por el cual se expide el reglamento técnico sobre los requisitos que debe cumplir la leche para el consumo humano que se obtenga, procese, envase, transporte, comercializa, expenda, importe o exporte en el país. (28 febrero de 2006). Bogotá. 2006.

13. Gallego-Castro L, Mahecha L, Angulo J. Milk production, quality and benefit: cost ratio of supplementing Holstein cows with Tithonia diversifolia. Mesoamerican Agr 2017;12(Suppl 1):357-370. 
14. Manterola H. Manejo nutricional y composición de la leche. El desafío de incrementar los sólidos totales en la leche. Una necesidad de corto plazo. Circular de extensión Técnico Ganadera. Universidad de Chile 2008;(33):1-20.

15. Cañas A, Restrepo B, Ochoa J, Echeverri A, Cerón-Muñoz M. Estimación de las curvas de lactancia en ganado Holstein y BON x Holstein en trópico alto colombiano. Rev Lasallista Invest 2009;6(1):35-42.

16. Ogola H, Shitandi A, Nanua J. Effect of mastitis on raw milk compositional quality. J Vet Sci 2007;8(3):237-242.

17. Herrera-Angulo A, Mora-Luna R, Isea-Chávez J, Eslava J, Darghan A. Producción y composición química de leche de vacas F1 Holstein x cebú suplementadas con dos fuentes de nitrógeno no proteico. Rev Científica 2017;7(2):119-130.

18. Hradecká E, Panicke L, Hanusová L. The relation of GH1, GHR and DGAT1 polymorphisms with estimated breeding values for milk production traits of German Holstein sires. Czech J Anim Sci 2008;53(6):238-245.

19. García C, Montiel R, Borderas T. Grasa y proteína de la leche de vaca: componentes, síntesis y modificación. Arch Zootec 2014;63:85-105.

20. Heck J, Schennink A, Van-Valenberg H, Bovenhuis H, Visker M, Van-Arendonk J, VanHooijdonk A. Effects of milk protein variants on the protein composition of bovine milk. J Dairy Sci 2009;92(3):1192-1202.

21. Schopen G, Heck JM, Bovenhuis H, Visker M, Van-Valenberg H, Van-Arendonk J. Genetic parameters for major milk proteins in Dutch Holstein-Friesians. J Dairy Sci 2009;92(3):1182-1191.

22. Brinez W, Valvuena E, Castro G, Tovar A, Ruíz-Ramírez J. Algunos parámetros de composición y calidad en leche cruda de vacas doble propósito en el municipio Machiques de Perijá. Estado Zulia, Venezuela. Rev Científica 2008;18(5):607-617.

23. Jacob M, Jaros D, Rohm H. Recent advances in milk clotting enzymes. Int J Dairy Technol 2011;64:14-33.

24. Gallier S, Gragson D, Cabral C, Jiménez-Flores R, Everett D. Composition and fatty acid distribution of bovine milk phospholipids from processed milk products. J Agr Food Chem 2010;58(19):10503-10511. 
25. Mojica J, Castro E, Silva J, Hortúa H, García L. Producción y calidad composicional de la leche en función de la alimentación en ganaderías doble propósito del departamento del Cesar. Bogotá (Colombia): CORPOICA. 2013.

26. Carulla JE, Ortega E. Sistema de producción lechera en Colombia: retos y oportunidades. Archiv Latinoam Prod Anim 2016;24(2):83-87.

27. Bobbo T, Ruegg PL, Stocco G, Fiore E, Gianesella M, Morgante M, Cecchinato A. Associations between pathogen-specific cases of subclinical mastitis and milk yield, quality, protein composition, and cheese-making traits in dairy cows. J Dairy Sci 2017;100(6):4868-4883. 